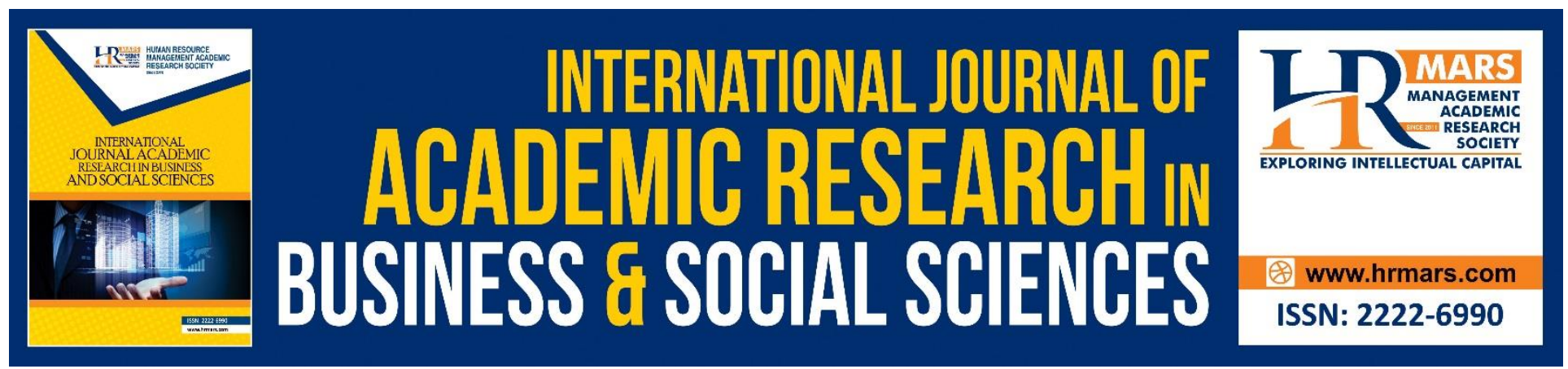

\title{
Analysis for Claim that Door of ljtihad is Closed in Muslim Community
}

Abd. Rasyid Idris \& Basri Ibrahim

To Link this Article: http://dx.doi.org/10.6007/IJARBSS/v10-i9/7883

DOI:10.6007/IJARBSS/v10-i9/7883

Received: 07 July 2020, Revised: 30 July 2020, Accepted: 19 August 2020

Published Online: 20 September 2020

In-Text Citation: (Idris, \& Ibrahim, 2020)

To Cite this Article: Idris, A. R., \& Ibrahim, B. (2020). Analysis for Claim that Door of ljtihad is Closed in Muslim Community. International Journal of Academic Research in Business and Social Sciences. 10(9), 898-911.

Copyright: (C) 2020 The Author(s)

Published by Human Resource Management Academic Research Society (www.hrmars.com)

This article is published under the Creative Commons Attribution (CC BY 4.0) license. Anyone may reproduce, distribute, translate and create derivative works of this article (for both commercial and non-commercial purposes), subject to full attribution to the original publication and authors. The full terms of this license may be seen

at: $\underline{\text { http://creativecommons.org/licences/by/4.0/legalcode }}$

\section{Vol. 10, No. 9, 2020, Pg. 898 - 911}




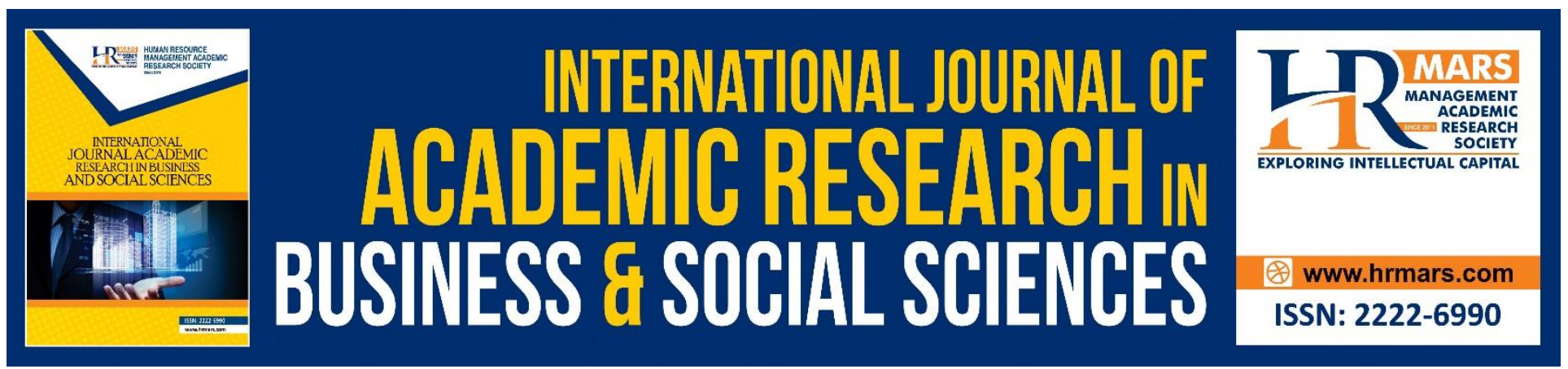

\title{
Analysis for Claim that Door of ljtihad is Closed in Muslim Community
}

\author{
Abd. Rasyid Idris ${ }^{1} \&$ Basri Ibrahim ${ }^{2}$ \\ ${ }^{1}$ Universiti Islam Malaysia, Cyberjaya, Malaysia, ${ }^{2}$ Universiti Islam Malaysia, Cyberjaya, \\ Malaysia/Faculty of Islamic Contemporary Studies, Universiti Sultan Zainal Abidin, Terengganu, \\ Malaysia. \\ Email: acsid@hotmail.com
}

\begin{abstract}
These questions of ijtihad, taqlid and sect more or less influence community's stance to practice of religion. They are always discussed along with community's concern to their religious affairs. This is because the nas and evidences of syarak are limited to what revealed upon Rasulullah S.A.W more than 1400 years ago but issues and problems of the people keep on developing. Situation of Muslim community in the world from time to time some also differ from what experienced by the Companions during revelation era. Thus, any call to shut off the door of ijtihad and being enough with what uttered by mujtahid scholars are seen as a stance contradicting with attributes of Islam which are divinely, universal, flexible and realistic. Therefore, the objective of this writing is to evaluate points of those who claim that the door of ijtihad is shut off by decease of the four imams of sect. Methods employed in this writing were of qualitative research. Data were collected from books discussing on this matter either specifically such as in Usul Fiqah and Maqasid or generally such as in Fiqah and others. Findings from this study are the claim that ijtihad is only limited to the four imams of sect is contradicting with the stance of those imams, violating the nature of scholarship, and differing from historical fact and reality of scholars' practice.
\end{abstract}

Keywords: Ijtihad, Taqlid, Ittiba', Sect.

\section{Introduction}

There are some among the community who are satisfied with inherited practices from generations. They depend totally to belief of surrounding community or at least, depend to what taught by the religious group. When awareness arises to peer into religion among the community, conflict happens. This is because there are community members who put their effort to develop their selves through wider learning and reading. Moreover, in this open sky era now, there are many sources of reference easier to access. They concern more in evaluation of each religious belief and action practised to ensure the wellbeing of religious practice. In the spark of religious reformation, appears demand for religious personnel to perform ijtihad to handle community's enquiries that become more developed and challenging. Besides that, the group that are able to study are also called to evaluate religious 
practices in a wider form across the binding and boundary of sect. As a reaction to this progress, appears a group prohibiting any effort of ijtihad and assuming that after the time of the four imams of sect, the door of ijtihad is closed. Efforts of performing only bring community to a play or taking for granted the laws decided by past scholars. This surely invites danger to religion and derails its doer to the valley of deviation and Allah's wrath. This reaction is too much. It is such as an escape mean for some people that status-quo rooting in the community is not abolished and argued. Some religious personnel are comfortable with ignorant community's full dependence to whatever they utter without doing evaluation and research. The demand to know deeper arguments and evidences prevents them from taking for granted in delivery of religion. The ability of audience to pose scholarly questions is like challenging the credibility of religious personnel. Consequently, the people who do that are regarded as violating the ijma' (indeed it is just an agreement of local community), opposing 'uruf, not respecting the scholars and elders, then are regarded as anti-sect. However, it is undeniable that the call for this ijtihad openness must have its limit as the capabilities of knowledge between human are not equal. If it is allowed for anybody to perform ijtihad without knowledge and methodological discipline, it can invite harm. It is worried that there would appear a group who make fun of religious laws or look down on religion.

Based on observation, it was found that there are several studies discussing on ijtihad, taqlid and others either supporting or opposing. For example, Irsyad al-Nuqqad ila Taysir al-litihad (al-San'ani, 1985), al-ljtihad al-Mu'asir bayna al-Indibat wa al-Infirat (al-Qaradawi, 1994), Asyaddu al-Jihad fi Ibtal Da'wa al-ljtihad (al-Naqsyabandi, 1994), Talfiq Beramal Dengan Pelbagai Mazhab (Malik, 2005) and Bahaya Anti Mazhab (Jabatan Mufti Pulau Pinang, 2017).

The objective of this writing is to prove the fragility of arguments claiming that the door of ijtihad is shut off. Besides that, this writing is also to clarify question and worrisome arising when the door of ijtihad is kept open and to state several disciplines lined by the scholars so that this pure effort is not misused by the group who make fun of religion.

\section{Research Methodology}

This article employed qualitative study in gaining its findings. Data were processed through document analysis found from scholars' writings regarding ijithad, taqlid and others either as positive or negative. Besides that, it also benefits question and answer session found in social websites. In context of this article, this qualitative method was implemented to understand deeply the arguments posed by both differing sides. Argument also includes several issues related such as maqasid syariah, practice of sect, taking rukhsah and others. Data collected were analysed and elaborated through inductive, deductive and comparative methods to obtain suitable results compatible with the determined objectives.

\section{Findings}

The claim that after the four imams of sect nobody can perform ijtihad is false. That also applies to the statement obligating the public to only hold to a sect without examining the strength of its evidence and argument where it also contradicts with the imams' stance. Next, current reality proves that personal or group ijtihad coming across existing Figh sects have become a norm. The strength of argument and benefit of community become the main factors in the process of scholars' ijtihad. It 
INTERNATIONAL JOURNAL OF ACADEMIC RESEARCH IN BUSINESS AND SOCIAL SCIENCES

Vol. 10, No. 9, 2020, E-ISSN: 2222-6990 @ 2020 HRMARS

should be differentiated between the groups who are anti-sect with those who are anti-extremism of sect.

\section{ljitihad, Taqlid and Ittiba'}

ljtihad means a hard effort of obtaining religious laws which are akli or naqli, which is qat'ie or zanni in the form where the soul feels unable to add more (al-Kafawi, 1994:44). While taqlid is "following opinion of an individual whose words are not religious evidence without any argument" (al-Syawkani, 1418H: 860-861). There is another term being in the middle of ijtihad and taqlid, it is called ittiba'. The term ittiba' refers to what is convicted upon it with evidence" (al-Fallani,1997:127). In short words, the ittiba' occurs when a person follows an opinion of scholar by knowing its evidence and argument, while he is considered doing taqlid if its belief is without evidence and reference.

\section{Claim that the Door of ljtihad is Closed}

Muslim community are divided into several stances regarding ijtihad issue. Some believe that for each time, there would a qualified scholar to perform ijtihad for continuity of religious practice in each different era. It becomes an instrument for development of community and strengthening of religion (al-Qaradawi, 1994:3). However, there are also those who opine that the door of ijtihad has been closed since the era of imams of sect: Hanafi, Maliki, Syafi'ie and Hanbali. Therefore for them, any belief regarding religious laws must only surround these 4 sects only. Holding to other than them is prohibited, deviating and qualified of torment upon it (al-Naqsyabandi, 1994:18). Even more, some are more extreme prohibiting taqlid to other than these four imams even though it agrees with Companions r.a's opinion, authentic hadis and Quranic verses. Whoever exits from these four sects, is deviated and deviating bringing him to infidelity. They claim, taking understanding from explicit meaning of al-Quran and sunah derives from infidelity (al-Sawi: 1192). Upon this over-extremism, appears a claim as quoted by Ibn 'Abidin al-Hanafi: "Prophet Isa Bin Maryam when descends in the end time later and also al-Mahdi when raised by Allah later will judge by Hanafi sect" (Ibn-'Abidin, 1966. 1:39).

That is the strictness and extremism of some of people to the four sects. Those who believe as this, refer it to several evidences, among them:

a. Nas of al-Quran. Allah S.W.T said:

Translation: You should obey Allah, obey Rasul and Ulil amri among you.

(al-Quran, 4: 59)

The verse states that after obedience to Allah and rasul, human is obligated to obey Ulil amri. Scholars of tafsir clarify that what is meant by ulil amri is the scholars (al-Razi, 1995.4:113-114). According to al-Naqsyabandi, this verse obligates obedience to scholars generally but then it is limited to four mujtahid scholars only as there is nobody after them who is equal with their knowledge and piousness. Their claim, this has been agreed by all scholars. He also said that Usul scholars agreed that other than level of mujtahid mutlak, a person is still named as a layman and muqallid even though he is a knowledgeable person (al-Naqsyabandi, 1994:10-11). Therefore, he referred the established basis to al-Razi who emphasised that layman is obligated to perform taqlid to mujtahid. Due to inexistence of mujtahid mutlak in this world after the four imams, then it is obligatory for the whole community to do taqlid to only these four Fiqh sects. 
INTERNATIONAL JOURNAL OF ACADEMIC RESEARCH IN BUSINESS AND SOCIAL SCIENCES Vol. 10, No. 9, 2020, E-ISSN: 2222-6990 @ 2020 HRMARS

He also criticised the people who claimed that it is permitted to perform ijtihad in the time after the four imams. All of them only depend on the books written by imams of mujtahid and their students, guided by usul and furu' developed by those mujtahidin. Therefore, it is an ijmak that it is compulsory to perform taqlid to these four sects only (al-Naqsyabandi, 1994:12).

b. Hadis of Prophet SAW. Rasulullah S.A.W said:

Translation: The best of generation is my generation, then those after them, then those after them.

(al-Bukhari: 2652; Muslim: 2533)

Al-Naqsyabandi claimed that there is no one that can be performed taqlid to except al-ma'sum which is Prophet S.A.W. as there should be no mistake occurring in Prophet S.A.W. Then, who can be perform taqlid to are people who were admitted by Prophet S.A.W. as the best generation. Those are the two generations after Prophet and His Companions r.a. The first generation received knowledge directly from Prophet S.A.W. but they did not compile all that were from Prophet S.A.W. Thus, they did not know between general and specific evidences and also between nasikh and mansukh. The subjects were only compiled during the second generation, then they memorised all that were compiled. In spite of that, they were not adequate of tafaqquh understanding the subjects. The matter was only completed by the third generation. They compiled, understood and completed Islamic legislative system then this religion was perfected. This generation had twelve scholars in which each of them had his own followers. After that, their sects disappeared until only four of them who remain until now (al-Naqsyabandi, 1994:15). Upon this basis, it is obligatory to hold to only these four sects. If there is anyone who claims inexistence of evidence from al-Quran and hadis obligating the taking of opinion from these four imams, then the answer is: evidence from al-Quran and hadis states generally and specifically that holding to al-Kitab and hadis is compulsory. Do the four sects flee from guidance of al-Quran and hadis? (al-Naqsyabandi, 1994:13).

c. Agreement of scholars (ijmak ulama):

Scholars from all places and time have admitted the excellence of knowledge and obligation to follow these four sects, tadayyun (practise religion) with them and taqarrub (being close) to Allah through it. Scholars of Qutub and walis (pious people) such as Abdullah bin al-Mubarak, al-Junaid al-Baghdadi, Ma'ruf al-Karkhi, Abd al-Qadir al-Jailani, al-Suhrawardi and many more who possessed kasyaf and inspiration from Allah also performed taqlid to these four sects (al-Naqsyabandi, 1994: 14,19-20). AlSya'rani stressed that people of kasyaf had agreed that those mujtahid imams were the heir of revelation from Prophet S.A.W. as Prophet was maksum (protected) from any mistake, then also those who are the heirs. They are mahfuz (guarded) from mistake also. If there is any mistake, it is just because they have not seen the evidence. Therefore, their ijtihad is like evidence of religion (nas syarak) obligated of practice. Extraction of laws by the mujtahids is the decree from Allah (alNaqsyabandi, 1994: 12).

\section{Conclusion from opinions and arguments posed by this group is:}

i. Not any human can interact with evidence from al-Quran and sunah. If someone is not a mujtahid then he will go astray and can become infidel.

ii. There is no mujtahid anymore after the era of four imams of sect. 
INTERNATIONAL JOURNAL OF ACADEMIC RESEARCH IN BUSINESS AND SOCIAL SCIENCES Vol. 10, No. 9, 2020, E-ISSN: 2222-6990 @ 2020 HRMARS

iii. Cannot take opinion from Companion who contradicted with opinion of existing four Figh sects.

\section{Discussion of Arguments}

There is no single Quranic verse even authentic hadis from Prophet S.A.W obligating taqlid to only one of the four sects, moreover specifying only to one of them. While the verse that can be related to this topic is only a form of general command to human to enquire knowledgeable people if a certain matter is unknown. Allah said:

Translation: Then should you ask Ahli Dzkir (knowledgeable people) if you do not know.

(al-Quran, 16: 43)

Nevertheless, on account of the group obligating this has posed several arguments comprising of Quranic verses, hadis and ijmak, then it is necessary to discuss it comprehensively.

Verse 59 surah al-Nisa' taken as evidence is clear that it obligates obedience to Allah and His Messenger in absolute without any doubt. That is the main obedience. However, scholars of tafsir bind obedience to Ulil Amri either they are scholars or umara' (rulers) to the former main obedience. Therefore, any opinion of scholar not complying with al-Quran or hadis is not compulsory of obedience. This is what stressed by every imam of the sects.

\section{Abu Hanifah}

Scholars have quoted his renowned words: "When authentic a hadis is, then it is my sect" (Ibn 'Abidin, 1966.1:63). When he was asked on his stance to the fatwa that he produced: "If you say with an opinion while Book of Allah defies it? He answered: Abandon my words for words of Allah. He was asked more, if Rasulullah S.A.W's words defies it? He answered: Abandon for the sake of Rasulullah S.A.W's explanation. He was asked more, if opinion of the Companions (of Rasulullah) defies it? He answered: Abandon my words for words of the Companions r.a”' (al-San'ani, 1985:141-142).

\section{Malik bin Anas}

He owned a famous saying calling for human to hold firmly to sunnah of Rasulullah S.A.W and leave any words defying it, including his own words. He said: "Truly I am only a mere human that can be wrong, can also be right. Then examine you all my opinion, anything that agrees with al-Kitab and sunah then take it and anything clashing with al-Kitab and sunah then leave it" (al-Fallani, 1997:196). When Khalifah Harun al-Rasyid intended to make the famous book written by him al-Muwatta' as the official reference by the public, Malik insisted of not permitting it. He stated that his book did not gather all inherited knowledge of Rasulullah S.A.W, in fact the knowledge had been disseminated by the Companions to the whole country. Therefore, each state should hold to whatever they inherit from the Companions' knowledge (al-Ghazali, n.d.1:39).

\section{Muhammad bin Idris al-Syafi'ie}

Al-Syafi'ie was one of the scholars of sect quoted by many regarding firm hold to sunah of Prophet S.A.W. Ahmad bin Hanbal as his student narrated that al-Syafi'ie had stressed that to him that: "If authentic a hadis is by your side, tell me so that I will hold to it" (al-Fallani,1997:263). Al-Syafi'ie also 
INTERNATIONAL JOURNAL OF ACADEMIC RESEARCH IN BUSINESS AND SOCIAL SCIENCES

Vol. 10, No. 9, 2020, E-ISSN: 2222-6990 @ 2020 HRMARS

said: "Muslims agreed that whoever is clear to him the sunah of Rasulullah S.A.W, it is not halal for him to abandon the sunah for anyone's words" (al-Fallani, 1997:169).

\section{Ahmad bin Hanbal}

Abu Daud quoted his teacher's words Ahmad bin Hanbal: "Do not you do taqlid in your religious affairs to anyone from among them (al-Auza'ie atau Malik), instead what comes from Prophet S.A.W and his Companions, take it. Then (take) from the tabi'in generation....". He did not only prohibit taqlid to the scholars but also prohibit from doing taqlid to him also. His famous saying: "Do not perform taqlid to me, do not perform taqlid to Malik and also to al-Thawri. Take (evidence and argument) from where they took it" (al-San'ani,1985:143).

All these words of imams of the sect converge to non-obsession to their opinion and sect. Instead, what to be held firmly is words of Allah and sunah of His messenger more than any human's opinion regardless of how excellent is their knowledge. Besides that, it is also a recognition from them to one's scholarship. Benchmark for correct stance and opinion is how far it complies with guidance from al-Quran and al-sunah. Thus, limiting mujtahid imam to only four individuals is a claim without any religious evidence. Historical reality indicates that there were so many scholars from generation to generation who had performed ijtihad differing from their own imams of sect. This can be witnessed in historical development of the sects itself.

Abu Hanifah was not alone in the establishment of Hanafi sect. This school of thought is like a sharing of ijtihad between him and his students, thus there were al-Qadi Abu Yusuf, Muhammad alHasan al-Syaibani and Zufar in the establishment of fatwa in the sect. They did not always agree with each other in every matter, instead in their several fatwas they had different stands between each other. These differences were until they are able to be compiled as a thesis of higher learning in Fiqh discipline by Sawasy bin Yusuf in Al-Masa'il allati ikhtalafa fiha A'immat al-Hanafiyyah al-Thalathah fi Fiqh al-'Ibadat. The existing differences also cause many Hanafi scholars to refer their fatwas in ritual matters to Abu Hanifah's opinion, in legislative and judicial to Abu Yusuf's and in familial and inheritance to Muhammad al-Hasan al-Syaibani's (Ibn-'Abidin, 1966.1:26).

Malik bin Anas imam Dar al-Hijrah had been opposed by one of his own main students which was al-Syafi'ie that ultimately established his own school of thought differing from the teacher he familiarised with since small. Besides that, lectures by Malik were also attended by al-Syaibani who was one of the pioneers of Hanafi sect. Even though al-Syaibani narrated al-Muwatta' book from his teacher, but he still held to Abu Hanifah's sect. However, as stated previously, there are many differences in fatwa of sect between al-Syaibani and his teacher, Abu Hanifah. Besides that, there was another student Malik named Asad bin al-Furat who then became a qadi in Qairawan city. This was Asad who had gathered the answers that he posed to Ibn al-Qasim another main student of Malik producing Al-Asadiyah book. However, many scholars of Maliki sect who were not satisfied with the method taken by Asad due to the influence of Hanafi sect contained in it. The cause was that after returning to Iraq, Asad then studied Hanafi sect from students of Abu Hanifah. Due to dissatisfaction among Maliki scholars to Risalah al-Asadiyah then appeared the book declared as the main reference by the sect after Malik's Muwatta' which is al-Mudawwanah written by Sahnun (al-Asyqar,1996:122123). 
INTERNATIONAL JOURNAL OF ACADEMIC RESEARCH IN BUSINESS AND SOCIAL SCIENCES Vol. 10, No. 9, 2020, E-ISSN: 2222-6990 @ 2020 HRMARS

Al-Syafi'ie meanwhile established his sect and became well-known as it had two schools of thought. For mazhab qadim (old), he developed while in Iraq. While for mazhab jadid (new), he built it after moving to Egypt. This is because he always prioritised evidence compared to his own opinion. He did not hesitate to retract his fatwa assumed to contradict with evidence from al-Quran and hadis (Abu Syamah, 3:33). He declared that his sect taken into account is the new one (jaded), it is like a filtering and refinery to his old school of thought. Scholars of Syafi'ie agree that the one accounted as Syafi'ie sect is the new one and not the old one as he had retracted his old fatwa to new fatwa (alJuwaini, 1399H.2: 366). In spite of that, there are more than twenty problems in Fiqh of Rituals where scholars of sect make fatwa different from fatwa of imam, instead they clarify al-Syafi'ie's opinion in his old sect. This is not because they do not know that al-Syafi'ie had retracted his stance then assuming that it is the sect of al-Syafi'ie. Instead, it is because they opine that evidences supporting mazhab qadim in those matters are stronger. They are also mujtahid that can make fatwa (al-Asyqar, 1996:53). That has still not considered clashes between al-Syafi'ie and several of his main students such as al-Muzani and others. Ahmad bin Hanbal as the pioneer of Hanbali sect was also one of alSyafi'ie's students. The difference in opinion does not make them rivals at all.

Besides that, it is something comprehended in study of Fiqh Mazhab that there are many differences between scholars of sect. Final opinion in a certain sect is not necessary of the imam's own opinion. This can be found in various Fiqh issues in all sects (al-Munajjid.n.d: 247742).

Besides the four imams of mujtahid there are many more scholars before, during and after them who are champions of Fiqh. Each of them has his own ijthad, for example: 'Ata bin Abi Rabah, Tawus, al-Awza'ie, al-Thawri, al-Tabari, Daud al-Zahiri, Ibn Hazm al-Andalusi and many more. They may not inherit a systematic but their opinion and fatwa can be found in books of tafsir, syarah hadis and others. Moreover, scholars such as who left a great treasure such as al-Muhalla book explaining his sect. There are always along the time among scholars of sect who produce fatwa different from imam's fatwa and in fact it is more famous than the imam's opinion.

Scholars who live afterward do take benefit from usul and furu' built by sholars of sect. But it does not mean that they cannot have ijtihad different from those made fatwa by the imams. The needs of different community and situation sometimes need for change of fatwa. This is formed in a principle as; change of fatwa due to chane of time and place. Its basis is the obedience to Allah and provision of benefit to community.

a. The way to law establishment has been compiled in a knowledge known as Usul Fiqah. Almost all scholars agree that the first person who compiled this knowledge systematically was alSyafi'ie. However, there is no scholar who deny that the spirit and passion of the knowledge can be found scattered and separately in books of scholars before al-Syafi'ie. Thus, the claim that the knowledge was only completed in the third generation is a statement of no strong basis. Instead, this claim is seen as a trial to defy action of several scholars who hold to Companions' fatwa differing from scholars of sect. Its reason is that during era of Companion and tabi'in the knowledge about laws had still not been completed. This is an insane matter as most sects make opinion and fatwa of Companions as one of the sources of reference through its methods and conditions. Therefore, what should be taken from hadis on the best generation is that: so that there would be no one who dares to convey opinion violating the methods of salaf al-soleh not just in Fiqh, but also in every branches of religion. The issue of 
INTERNATIONAL JOURNAL OF ACADEMIC RESEARCH IN BUSINESS AND SOCIAL SCIENCES Vol. 10, No. 9, 2020, E-ISSN: 2222-6990 @ 2020 HRMARS

whether the four sects are out of guidance from al-Quran and hadis has been answered by words of the imams themselves as mentioned.

Regarding proofing system of sect through Usul Fiqah knowledge, until fifth Hijri century, the knowledge is divided into two streams. The first stream is Ahnaf stream represented by scholars of Hanafi sect meanwhile the second stream is Mutakallimin stream represented by majority of scholars which are the other three sects. Arrival of al-Syatibi through his work titled Al-Muwafaqat fi Usul alSyari'ah has brought a new dimension to Usul Fiqah knowledge. It is then followed by later scholars in writing of Usul Fiqah book. The book al-Muwafaqat combines both opposing streams and divided the sources of law extraction into the agreed and opposed one. It also presents the dimension of maqasid syariah as an important element in building of law. Therefore, if the ijtihad stops only to the four imams, then dries the treasure of Islamic knowledge and becomes barren the community's thought. Then there would be many new problems not existing in the past that cannot be solved. But by virtue of scholars' perseverance from time to time to perform ijtihad, the knowledge is nourished and the burden of community is lifted from the problems they face.

b. Ijmak claim is among the problems discussed in detail by scholars of Usul. It means the agreement of mujtahidin from community of Muhammad S.A.W in a certain t ime upon a law. Something is not regarded as ijmak except for the one that has no contradiction on it. Therefore, it cannot be done merely to claim ijmak in the matters obligating taqlid to only the four sects while there are so many scholars' words defying the claim. This can be proved:

i. That there is no narration from generation of salaf al-soleh prohibiting the public to take fatwa from any scholars in any problem (al-Hajuri,2:476). In fact, the refusal of Malik bin Anas in making his book al-Muwatta' as the main reference in Khilafah Harun al-Rasyid is the proof of the generation's openness in this issue.

ii. It is agreed by Muslim community that if a person embraces Islam, he is not obligated to hold to only a certain sect. Instead, he will follow his teacher's fatwa until arrives to him the knowledge to follow others. Due to that, scholars like al-Iraqi, al-Zarkasyi, 'Izz al-Din, al-Nawawi, al-Sya'rani, al-San'ani and many others stressed that the authentic one is that it is not obligatory to perform taqlid to one of the four sects (al-Hajuri, n.d.2:476).

If a comparison is made between the scholars who obligate taqlid to only the four sects without going out from it and the scholars who permit going out from the four sects then it can be found that there are many scholars at both sides. Each side presents their evidence. The higher number of supporters cannot be a proof that the stance is stronger than the opposing side, however evidences and arguments of their reference would be the decider of truth. However, the important message here is that, there is no ijmak of scholars obligating taqlid to only four sects. In fact, if it is considered, scholars who obligate the taqlid must comprise of muqallid also. Then words and instructions by muqallid cannot be an evidence of religion.

Then, castrating human's mind by prohibiting those who can perform ijtihad is a form of denial to Allah's bounties (al-San'ani, 1985:158). 
INTERNATIONAL JOURNAL OF ACADEMIC RESEARCH IN BUSINESS AND SOCIAL SCIENCES Vol. 10, No. 9, 2020, E-ISSN: 2222-6990 @ 2020 HRMARS

\section{People Qualified of ljtihad}

After the fragility of argument of those who obligate taqlid by reason that the door of ijtihad has been closed after the four imams, arises a question: who are qualified of ijtihad? Do all levels of community have right to perform ijtihad? Here arises again an argument in the differentiation between mujtahid, muqallid (people who do taqlid) and muttabi' (people who know evidence). Some scholars refuse to differentiate between muqallid and mujtahid while some of them differentiate between both as there is implication of it to the practice of sect.

There, the reality is that not all people are able to understand nas of al-Quran and Prophet S.A.W.'s hadis directly from their sources. Ability to understand nas needs mastery of instrumental knowledge and high intellectual ability. While the very Arabs whose al-Quran and hadis are in their mother tongue might still cannot understand it, moreover for those who are from other races. That is why scholars obligate sect, which is actually upon objective of preventing public from blindly performing ijtihad without knowledge. Opinion of the group who oppose sect is dangerous to the purity of religion as it is extracted by those who do not Arabic language (al-San'ani, 1985:6). Moreover, the ability of understanding provisions of religion (nas syarak) does not depend only on literal aspect but in fact there are several other skills that need to be mastered. Public are incapable of reaching the level of evidential understanding (al-San'ani, 1985:12).

However, appears a call to the public to leave sect and even prohibition of practising sect and it invites great harms. Among those appearing was a writer named al-Khajandi (al-Buti.n.d:12). He brought a thought that the existing sects are only mere scholars' opinions while human can still dig for laws directly from al-Quran and Sunah. The practice of sect is a deviated heresy, and it is even a fidelity for regarding the imams of sect as god (Jabatan Mufti Pulau Pinang, 2017:3-4). In Malay realm, the controversial writer A. Hasan who was also known as Hasan Bandung had described the taqlid of sect as something forbidden by Allah, His Messenger, Companions and even the imams of sect themselves prohibited it (Hasan, n.d:12). Extreme statements like these add further worrisome to the call of leaving the sect. The action could bring human to plunge into fraud upon Allah's and Rasul's name. Phenomenon of the Youngers frequently enquiring evidence during discussion of Fiqh books brings the intellects into a dilemma. Does it need to be answered according to sect or presented with evidence and argument? What feared is that the questions are not to increase understanding but pushed by hesitation to Fiqh of sect in consequent to the understanding that all laws can be dug directly from al-Quran and sunnah (Jabatan Mufti Pulau Pinang, 2017:13).

The next worrisome is that if a matter has dependable nas but due to ignorance of related nas or incapability of understanding existing nas, a person might defy the existence of it. Therefore, it is not weird for sayings of some among community directed towards community's practices such as: "it is not a sunnah", "it is unavailable in al-Quran", "it is a traditional invention of Malay community", "it is merely a custom", "it is a heresy" and various claims based on their teachers' method (Jabatan Mufti Pulau Pinang, 2017: 14). This disturbs the harmony of Malaysian Muslim community that has blended with Syafi'ie sect specifically in matters of rituals, marriage and Fardu Ain. In matters of financial transaction, crime, legislation and governmental contemporary issue, they are not bound to Syafi'ie sect only. This totally proves that holding to Syafi'ie sect in matters of fardu ain does not mean to reject other sects. Instead, this is because public cannot practise other than Syafi'ie sect (Jabatan Mufti Pulau Pinang, 2017: 14). However, some activists of the anti-sect movement have judged the practices blended among community as heresy while they are only branches of Fiqh. But by the action 
of convicting them a heresy, a small issue can become bigger (Jabatan Mufti Pulau Pinang, 2017: 15). Therefore, a message to the anti-sect group, do not decide something of khilaf (diversity of opinion) as heresy or final or closer to sunnah, more authentic and others. It might be true, but it cannot be forced upon the community as the community is not ready of practising other that Syafi'ie sect (Jabatan Mufti Pulau Pinang, 2017:22).

Conclusion from these worrisome is that public are not mujtahid, it is difficult for them to know and understand evidence. Therefore, they cannot perform ijtihad and it is compulsory to practise sect. Any question regarding evidence raised to trouble the ustaz or lecturers to explain its evidence besides trapping them between presenting fact of sect or evidence from al-Quran and sunah of Rasulullah S.A.W.

\section{Discussion of Arguments}

a. Human has many levels of knowledge ability and understanding. Therefore, the division of human into mujtahid, muttabi' and muqallid is actually aiming to do justice to each level. Even there are some who refuse to differentiate between muttabi' and muqallid, the result is still the same that responsibility born is based on one's ability to understand evidence and argument of religion. A person is not put responsibility more than his capability. Anyone cannot hide behind the term muqallid covering him to escape from seeking of knowledge and practising with the knowledge. What the religion obligates is only to those who reach the level of mujtahid, to perform ijtihad for himself either in absolute or in radius of followed sect's method. This has happened for generations until today. From that process, appeared thousands of scholars along the history of Muslim community. Some whose treasure of knowledge still remain in library and some have already disappeared. For those who get healthy mind, who can understand arguments of knowledge from systematic lectures, it is necessary for the, to practise religion based on learnt knowledge. The more he learns, logically the more will he understand his religion. The group lowest in their level of thinking compared with those previous two groups, is the real muqallid. He only needs to ask for laws of religion from a trusted teacher. What is posed as fatwa to him, that is his sect. That is the meaning of words by scholars that public do not have sect, instead their sect is the sect of mufti (the asked teacher)" (al-Laknawi, n.d.1: 51).

b. A muqallid cannot perform ijtihad. This is because his intellectual and knowledge ability prevent him from doing that. If it is still done, it is feared that he can deviate from truth and say on religion without knowledge. It is a crime in religion. But it does not also mean that he must practise with a particular sect only. Instead, what is obligatory upon him is seeking of knowledge at rate of his ability, the remaining depends on guidance from teacher whose religion is trusted. For the group whose intellectual ability is less, should put more effort in understanding religious evidence and argument in milieu of existing knowledge disciplines. It is regardless of whether he wants to hold to only a sect or wider from that. This depends on the system of study undertaken, ability to process academic discussion and life benefit undergone. From an aspect, processing of academic discussion is also a form of ijtihad in a limited context. It may be difficult but it is not impossible until the door of ijtihad should be closed. 
c. Striving of public in learning the religion should be celebrated and appreciated. In the situation of easier access of information compared to the past, it is a responsibility of community and authority to provide facilities supporting the effort. When the public strive to improve their ability, then religious personnel are encouraged more as from them the community hope for guidance. Through this process, it can eliminate the storytellers and riders of religion who for a long time take advantage of community's ignorance for their worldly benefit. If these groups feel threatened, then it is not weird if many restrictions to knowledge propagation knowledge happen.

d. If the public are claimed of incapable to practise other than Syafi'ie sect due to inability of knowledge, the reality shows that it can be fixed. Through properly arranged course, it can improve the ability. When the community know the variety of opinion, it can help them more in preservation of their life benefit. For example, fatwa declared by the religious authority of several states regarding the number of congregation for Jumaat prayer beginning from 15 May 2020 which is of 3-12 individuals only is the proof of goodness from diversity of sects. In the situation of facing this covid-19 pandemic, social distancing and prohibition of large-scale assembly have caused the symbols of greatness of Jumaat and congregational prayer to be enlivened. If we were to remain with the opinion in Syafi'ie sect which is 40 individuals enable Jumaat prayer to be performed, then safety risk is higher and the mosque officials will face difficulty to supervise the attending congregation. Thus, by choosing a more lenient opinion, then the Islamic symbols of greatness can be enlivened and benefit of community is not ignored (MAIPs, 2020. 7: 82; JAIS, 2020. 2:31). If these authorities keep on static with only a sect then there would be no fatwas easing the public more in practice of religion through a more flexible form.

e. Sayings doubting the community's practice should be evaluated justly. Voices enquiring of evidence should be entertained academically as it is a symbol of community's empathy to the practices as a preparation for the hereafter. Either it is done sincerely or not, let Allah judge it. But the seriousness in peering into religion should be appreciated and guided to be right on its path. It is the failure of explaining evidence and argument that becomes a factor leading to presence of sayings doubting the traditional practice. The solution is by presenting evidence and not by doubting the empathy of some from community. Next, it is true that the doubted matters do have religious reference? Or it is only a tradition without evidence? Disguising behind the brand 'this is khilaf' that cannot be argued, is not a good solution. The community are more exposed to issue of khilaf either it is muktabar which is based on strong evidence and argument or it is khilaf of not muktabar which has no evidential reference. Some time ago, the practice of safar bath, entertaing the spirits, getting rid of jinx (buang ancak) and others are led by imam and pak lebai (religious individual) in villages. However, when awareness of religion increases, it finally could eliminated as it is obvious that the practices contradict with religion. But if the reason that it is the practice of past people, it is khilaf, then until now the superstitions would still be strong in the community.

f. Communal harmony is really threatened of each clash is not managed properly. Thr group whose status-quo is threatened, income is affected, will still defy any effort of reformation. 
But for those who have no interest besides seeking for Allah's pleasure, they will surely prefer the authenticity evidence and argument. Next, if something is a khilaf of muktabar, every differing side should tolerate. If the one defended is a belief in Syafi'ie sect, it is necessary to ensure that whether it is really of Syafi'ie sect or only past tradition referred uncertainly to the sect. It may also be a heresy invented by past community. It may also be an opinion in other Fiqh sects. That is the importance of knowledge to differentiate true and fake practice.

\section{Conclusion}

Individuals able to examine evidence and evaluate argument which one is stronger. It is not necessary for them to perform taqlid to others. If there is any difference in opinion between modern scholars and past scholars, it does not mean that it is disgraceful as something made fatwa at a certain time is not necessarily suitable in other time. Something authentic at a time might be less authentic in other time. This is based on scholars' method as: "Change of fatwa due to change of place, time and customs" (al-Qaradawi (2), 2020). Public who are difficult to understand evidence and argument must take fatwa from scholars whose religion is trusted. His action should not be defied because as long as he holds to fatwa of imam mujtahid, he is still a Muslim. What is cursed is the fanaticism to sect or scholar until strong religious evidence and argument are turned back on.

Permission to perform ijtihad is the sign of freedom for opinion and respect for intellectuality by Islam. This flexible religion allows it to follow changes due to place and location. The condition is that it must be bound by general principles of Islam and its reality. Therefore, the existence of various sects, is assign of freedom for ijtihad. Restricting it will change the positive attribute of Islam into negative.

\section{Corresponding Author}

Abd. Rasyid bin Idris, Universiti Islam Malaysia, Cyberjaya, Malaysia.

Email: acsid@hotmail.com

\section{Acknowledgement}

Special thanks to the Majlis Agama Islam Dan Adat Istiadat Melayu Perlis for funding the research under Jamalullail Professorial Chair, Universiti Islam Malaysia.

\section{References}

Abu-Syamah. (n.d). Al-Mu'ammal li al-Raddi li al-Amr al-Awwal, Majmu'ah al-Rasa'il al-Muniriyyah, printed without date and publisher.

A Hasan. (n.d) Risalah al-Mazhab, Bangil: Pustaka Abdul Muis.

Al-Asyqar, U. S. (1996). Al-Madkhal ila Dirasah al-Madaris wa al-Mazahib al-Fiqhiyyah, Jordan: Dar al-Nafa'is.

Al-Buti, M. S. R. (n.d). al-Lamdhhabiyyah Akhtaru Bid'atin Tuhaddidu al-Syari'ah al-Islamiyya. Maktabah al-Farabi, $2^{\text {nd }}$ Ed.

Al-Fallani, S. M. M. (1997). Iqadh Humam Uli al-Absor li al-lqtida' bi Sayyid al-Muhajirin wa al-Ansar, Syarjah: Dar al-Fath.

Al-Ghazali, A. H. M. (n.d). Ihya' Ulum al-Din, Beirut: Dar al-Kutub al-'llmiyyah.

Al-Hajuri, M. H. F. (n.d). Al-Fikr al-Sami fi Tarikh al-Fiqh al-Islamiy, Beirut: Dar al-Kutub al-'Ilmiyyah. 
INTERNATIONAL JOURNAL OF ACADEMIC RESEARCH IN BUSINESS AND SOCIAL SCIENCES

Vol. 10, No. 9, 2020, E-ISSN: 2222-6990 @ 2020 HRMARS

Al-Juwaini, A.M. (1399H). Al-Burhan fi Usul al-Fiqh, Khalifah bin Hamd Ali Thani.

Al-Kafawi, A. B. A. M. (1992). Al-Kulliyyat Mu'jam fi al-Mustolahat wa al- Furuq al-Lughawiyyah.

Beirut: Mu'assasah al-Risalah.

Al-Laknawi, A. H. A. H. (n.d). 'Umdat al-Ri'ayah 'ala Syarh al-Wiqayah, Beirut: Dar al-Kutub al-Ilmiah. Al-Munajjid, M. S. (n.d). Al-Islam Su'al wa jawab. Islamqa.info.

Al-Naqsyabandi, D. S. B. (1994). Asyaddu al-Jlhad fi Ibtal Da'wa al-ljtihad, Istanbul: Ihlas Vakfi.

Al-Qaradawi, Y. (1994). Al-ljtihad al-Mu'asir bayna al-Indibat wa al-Infirat, Kaherah: Dar al-Tauzi' wa al-Nasyr al-Islamiyy.

Al-Qaradawi, Y. (n.d). Al-ljtihad al-Intiqa'i. www.al-qaradawi.net (10.5.2020).

Al-Razi, F. D. (1995). Al-Tafsir al-Kabir, Beirut: Dar Ihya' al-Turath al-'Arabiy.

Al-San'ani, M. I. (1985). Irsyad al-Nuqqad ila Taysir al-ljtihad, Kuwait: Al-Dar al-Salafiyyah.Al-Sawi, A. (n.d). Hasyiah al-Sawi 'ala Tafsir al-Jalalayn, Mesir: Dar al-Fikr.

Al-Syawkani, M. A. (1418H). Irsyad al-Fuhul ila Tahqiq al-Haqq min 'Ulama al-Usul. Edit. Syaaban Muhammad Ismail, Kaherah: Dar al-Salam.

Bahaya Anti Mazhab, Jabatan Mufti Pulau Pinang, $2^{\text {nd }}$ Ed., 2017.

Ibn-'Abidin, M. A. A. (1996). Hasyiah 'ala Radd al-Muhtar, Kaherah: Maktabah Mustafa al-Halabi.

Ibn-'Abidin, M. A. A. (n.d). Syarah 'Uqud Rasm al-Mufti, Majmu'ah Rasa'il Ibn 'Abidin,. No publisher.

Khairuldin, W. M. K. F. W., Hassan, S. A., Anas, W. N. I. W. N., Mokhtar, W. K. A. W., \& Embong, A. H. (2020). Al-Takyif Al-Fiqhi and its application in Islamic research methodology. Journal of Critical Reviews, 7(7), 462-467.

Jabatan Agama Islam Selangor, Pekeliling JAIS 01/006/2 Vol. 2 (31), 14 May 2020.

Kujabasy, S. Y. (n.d). Al-Masa'il allati ikhtalafa fiha A'immat al-Hanafiyyah al-Thalathah fi Figh al'Ibadat, Beirut: Dar al-Kutub al-'Ilmiyyah.

Majlis Agama Islam Perlis, Siaran MAIPs. 100-6 Vol. 7 (82), 8 May 2020. 